\title{
Analisis Pengaruh Pertumbuhan Pembiayaan Modal Kerja, Investasi dan Konsumsi Pada Perbankan Umum Syariah Terhadap Pertumbuhan Produk Domestik Regional Bruto (PDRB) Kalimantan Barat Periode 2009-2013
}

\author{
Hayet $^{*}$ \\ Universitas Tanjupura
}

\begin{abstract}
Islamic banking has an important role in stimulating the economy because of the intermediary function performed. Improved economy is reflected in the value of the Gross Regional Domestic Product (GRDP) of an area / region. Distribution of funding performed Islamic banking is given based on the purpose and use of the funds are classified into financing for working capital, investment and consumption. This research was to determine (1) the effect of the growth of working capital financing (MK), investment (I), and consumption in Islamic commercial banking on growth GRDP West Kalimantan. (2) Determine which variables are the most dominant influence on GRDP growth in West Kalimantan. Sources of data working capital financing, investment and consumption of Islamic banking statistics obtained from Bank Indonesia while the GRDP data from the Central Statistics Agency (BPS) of West Kalimantan. The analytical methods used were multiple linear regression with a significance level of 0.05 . The results of this research indicate that (1) the growth of working capital financing, investment and consumption in Islamic commercial banking simultaneously the effect on the GRDP growth in West Kalimantan. Partially, on the financing of investment and consumption variables there are significant positive effect on GRDP growth West Kalimantan. However, variable financing for working capital of individual negative and not significant. 2) The most dominant variable effect on the GRDP growth is financing consumption, followed by financing investment and working capital. The value of the coefficient of determination Adjusted R2 of 0.489, it means that the financing of working capital, investment, and consumption of Islamic commercial banking affect GRDP growth of 48.9 percent. While the rest influenced by other variables not included in this study.
\end{abstract}

Keywords: Islamic banking, Gross Regional Domestic Product, working capital financing, investment, consumption.

\section{PENDAHULUAN}

Bank Islam (islamic banking) atau selanjutnya disebut dengan bank syariah adalah bank yang menjalankan kegiatan usahanya berdasarkan prinsip syariah. Atau

\footnotetext{
Korespondensi: Hayet, Program Studi Ekonomi Islam, Fakultas Ekonomi dan Bisnis, Universitas Tanjungpura. Jalan Prof. Dr. H. Hadari Nawawi, Pontianak, Indonesia. Email: hayet_rakhi@ymail.com.
} 
dengan kata lain, bank syariah adalah lembaga keuangan yang usaha pokoknya memberikan pembiayaan dan jasa-jasa lainnya dalam lalu lintas pembayaran serta peredaran uang yang pengoperasiannya disesuaikan dengan prinsip syariat Islam. (Muhammad, 2011)

Kegiatan operasional perbankan syariah di Indonesia dimulai pada tahun 1992 melalui pendirian PT Bank Muamalat Indonesia Tbk. (PT BMI) atau 4 tahun setelah diregulasi. Operasional perbankan syariah di Indonesia didasarkan pada Undang-undang No. 7 tahun 1992 tentang perbankan yang kemudian diperbaharui dengan Undangundang No. 10 tahun 1998 dan diperbaharui lagi yang terbaru Undang-undang No. 21 tahun 2008 tentang perbankan syariah.

Perbankan syariah dalam menjalankan aktifitas usahanya dengan menghimpun dana dan menyalurkan kembali dengan memberikan pembiayaan kepada masyarakat. Pembiayaan dalam arti sempit merupakan pendanaan yang dilakukan oleh lembaga pembiayaan seperti bank syariah kepada nasabah. Sedangkan pembiayaan dalam arti luas berarti financing atau pembelanjaan yaitu pendanaan yang dikeluarkan untuk mendukung investasi yang telah direncanakan baik dilakukan sendiri maupun oleh orang lain. Berdasarkan tujuan penggunaannya, dibedakan dalam pembiayaan investasi, yaitu pembiayaan untuk pengadaan sarana atau alat produksi. Pembiayaan modal kerja, yaitu pembiayaan untuk pengadaan bahan baku atau barang yang diperdagangkan. Pembiayaan konsumtif yaitu pembiayaan yang ditujukan untuk pembelian suatu barang yang digunakan untuk kepentingan perseorangan.

Beberapa indikator ekonomi seperti pertumbuhan ekonomi, struktur ekonomi dan produktifitas pekerja diturunkan dari data yang disebut Produk Domestik Bruto (PDB) untuk tingkat nasional dan Produk Domestik Regional Bruto (PDRB) untuk wilayah provinsi dan wilayah di bawahnya. PDRB didefinisikan sebagai jumlah nilai tambah yang dihasilkan oleh seluruh unit usaha yang beroperasi dalam suatu wilayah tertentu. Besaran PDRB dihitung dengan satuan unit uang yang didasarkan pada harga tahun yang menjadi patokan dasar. PDRB atas dasar harga berlaku menggambarkan nilai tambah barang dan jasa yang dihitung dengan menggunakan harga yang terjadi pada tahun berjalan, sedangkan PDRB atas harga konstan menunjukkan nilai tambah barang dan jasa tersebut yang dihitung menggunakan harga pada satu waktu tertentu sebagai dasar.

Kinerja pembangunan perekonomian Kalimantan Barat terus mengalami pertumbuhan yang positif dengan trend yang terus meningkat setiap tahunnya. Pertumbuhan ekonomi Kalimantan Barat pada tahun 2013 mengalami kenaikan sebesar 0,27 persen menjadi 6,08 persen di bandingkan pertumbuhan tahun sebelumnya sebesar 5,81 persen. Hal ini mencerminkan jumlah barang dan jasa yang dihasilkan oleh faktor-faktor produksi mengalami peningkatan yang lebih tinggi selama periode tersebut dibanding tahun sebelumnya. Pada tahun 2013, pertumbuhan ekonomi Kalimantan Barat lebih tinggi dibanding dengan pertumbuhan ekonomi secara nasional sebesar 5,78 persen. Selama periode tahun 2009-2013 rata-rata pertumbuhan ekonomi Kalimantan 
Barat sebesar 5,57 persen atau lebih rendah jika dengan pertumbuhan ekonomi nasional sebesar 5,81 persen.

Nilai Produk Domestik Ragional Bruto (PDRB) Kalimantan Barat atas dasar harga berlaku pada tahun 2013 sebesar 84.956,23 Miliar, lebih tinggi dibanding dengan tahun sebelumnya sebesar 74.969,66 Miliar. Jika di lihat dari PDRB berdasarkan atas dasar harga konstan, pada tahun 2013 nilai PDRB Kalimantan Barat sebesar 36.075,10 Miliar, sedangkan tahun 2012 nilai PDRB Kalimantan Barat sebesar 34.007,56 Miliar. Kondisi tersebut di dorong oleh meningkatnya produksi sektor perkebunan dan pertanian Kalimantan Barat seperti komoditas CPO dan Karet yang dipicu oleh permintaan global dan mulai membaiknya harga kedua komoditas tersebut di pasar internasional.

\section{Tabel 1. Pertumbuhan PDRB Kalimantan Barat Berdasarkan ADH Berlaku, ADH Konstan dan Pertumbuhan Ekonomi Indonesia tahun 2009-2013}

\begin{tabular}{ccccc}
\hline Tahun & $\begin{array}{c}\text { PDRB ADH Berlaku } \\
\text { (Rp Miliar) }\end{array}$ & $\begin{array}{c}\text { PDRB ADH Konstan } \\
\text { 2000 (Rp Miliar) }\end{array}$ & $\begin{array}{c}\text { Pertumbuhan } \\
\text { Ekonomi KalBar } \\
\text { (Persen) }\end{array}$ & $\begin{array}{c}\text { Pertumbuhan } \\
\text { Ekonomi Nasional } \\
\text { (Persen) }\end{array}$ \\
\hline 2009 & $53.865,79$ & $28.754,36$ & 4,76 & 4,54 \\
2010 & $54.234,14$ & $29.001,84$ & 5,35 & 6,1 \\
2011 & $66.915,62$ & $32.141,38$ & 5,85 & 6,4 \\
2012 & $74.969,66$ & $34.007,56$ & 5,81 & 6,23 \\
2013 & $84.956,23$ & $36.075,10$ & 6,08 & 5,78 \\
\hline
\end{tabular}

Sumber : Badan Pusat Statistik (BPS) Kalimantan Barat, Edisi 5 Februari 2014

Keterangan : ADH (Atas Dasar Harga)

Meskipun pertumbuhan ekonomi Kalimantan Barat secara rata-rata lebih rendah dibandingkan pertumbuhan ekonomi nasional, hal yang menarik adalah kondisi perbankan umum syariah di Kalimantan Barat mampu tumbuh lebih cepat di bandingkan dengan perbankan umum syariah secara nasional. Perkembangan perbankan umum syariah di Kalimantan Barat terus mengalami pertumbuhan yang signifikan setiap tahunnya. Hal ini bisa kita lihat dari beberapa indikator baik dari sisi kemampuan bank umum syariah dalam menghimpun dan maupun dalam mengelola resiko yang ada, seperti Aset, Pembiayaan (financing), Dana Pihak Pihak Ketiga (DPK), rasio kemampuan bank menyalurkan pembiayaan terhadap dana yang dihimpun (financing to deposit rasio), dan resiko pembiayaan (non performing financing). Secara tahunan, indikator bank umum syariah menunjukkan pertumbuhan yang positif.

Perkembangan aset perbankan umum syariah di Kalimantan Barat mengalami peningkatan yang signifikan. Pada tahun 2013, jumlah aset yang dimilik perbankan umum syariah mencapai 3.161 Miliar meningkat dibanding tahun sebelumnya sebesar 2.478 Miliar. Peningkatan pertumbuhan Aset perbankan syariah pada tahun 2013 
mencapai 27,56 persen. Selama periode tahun 2010 hingga 2013, pertumbuhan aset tertinggi terjadi pada tahun 2012 dengan persentase pertumbuhan sebesar 44,24 persen.

Laporan kajian ekonomi regional (KER) Bank Indonesia menyebutkan bahwa proporsi aset perbankan umum syariah di Kalimantan Barat lebih tinggi dibanding proporsi perbankan umum syariah secara nasional. Proporsi aset perbankan umum syariah di Kalimantan Barat sebesar 6,74 persen dibandingkan proporsi aset bank umum konvensional, sedangkan proporsi aset perbankan umum syariah nasional sebesar 4,7 persen terhadap perbankan umum konvensional.

Perkembangan penyaluran pembiayaan (financing) perbankan umum syariah di Kalimantan Barat mengalami pertumbuhan yang tinggi. Jumlah pembiayaan yang berhasil disalurkan pada tahun 2013 sebesar 2.456 Miliar meningkat dibanding tahun sebelumnya sebesar 1.740 Miliar. Peningkatan pertumbuhan pembiayaan perbankan umum syariah mencapai 41,15 persen. Selama periode tahun 2010 hingga 2013, pertumbuhan pembiayaan tertinggi terjadi pada tahun 2012 dengan persentase pertumbuhan sebesar 61,11 persen.

Tabel 2. Jumlah Aset, Pembiayaan, Dana Pihak Ketiga, FDR, NPF Perbankan Umum Syariah di Kalimantan Barat tahun 2010-2013

\begin{tabular}{ccccccccc}
\hline \multirow{2}{*}{ Tahun } & \multicolumn{2}{c}{ Aset } & \multicolumn{2}{c}{ Pembiayaan } & \multicolumn{2}{c}{ DPK } & \multicolumn{1}{c}{ FDR } & NPF \\
\cline { 2 - 8 } & (Rp Miliar) & (Persen) & (Rp Miliar) & (Persen) & (Rp Miliar) & (Persen) & (Persen) & (Persen) \\
\hline 2010 & 1.350 & 25,00 & 720 & 22,45 & 717 & 31,80 & 100,50 & 0,58 \\
2011 & 1.718 & 27,26 & 1.080 & 50,00 & 1.066 & 48,68 & 101,26 & 0,33 \\
2012 & 2.478 & 44,24 & 1.740 & 61,11 & 1.315 & 23,36 & 132,34 & 0,57 \\
2013 & 3.161 & 27,56 & 2.456 & 41,15 & 1.598 & 21,52 & 153,64 & 0,71 \\
\hline
\end{tabular}

Sumber: Bank Indonesia

Dilihat dari penghimpunan dana pihak ketiga (DPK), jumlah dana pihak ketiga yang berhasil dihimpun bank umum syariah di Kalimantan Barat hingga akhir tahun 2013 mencapai 1.598 Miliar atau mengalami pertumbuhan sebesar 21,52 persen dibanding tahun sebelumnya. Selama periode 2010 hingga 2013, pertumbuhan dana pihak ketiga mengalami kenaikan tertinggi terjadi pada tahun 2011 dengan persentase sebesar 48,68 persen.

Tabel 3. Jumlah Pembiayaan, Dana Pihak Ketiga, FDR, NPF Perbankan Umum Syariah di Indonesia tahun 2010-2013

\begin{tabular}{ccccccc}
\hline & \multicolumn{2}{c}{ Pembiayaan } & \multicolumn{2}{c}{ DPK } & FDR & NPF \\
\cline { 2 - 7 } Tahun & $($ Rp Miliar $)$ & $($ Persen $)$ & $($ Rp Miliar $)$ & $($ Persen $)$ & (Persen) & $($ Persen $)$ \\
\hline 2010 & 68.181 & 45,42 & 76.036 & 45,46 & 89,67 & 3,02 \\
2011 & 102.651 & 50,56 & 115.415 & 51,79 & 88,94 & 2,52 \\
2012 & 147.505 & 43,7 & 147.512 & 27,81 & 100,00 & 2,22 \\
2013 & 184.122 & 28,82 & 184.122 & 24,82 & 100,32 & 2,62 \\
\hline
\end{tabular}

Sumber: Bank Indonesia 
Perkembangan penyaluran pembiayaan (financing) lebih cepat dibandingkan pertumbuhan dana pihak ketiga (DPK). Hal ini tercermin dari financing to deposit rasio (FDR). Kondisi ini menunjukkan membaiknya tingkat intermediasi perbankan umum syariah di Kalimantan Barat. Pada tahun 2013, Jumlah pembiayaan yang disalurkan terhadap dana pihak ketiga mencapai 153,64 persen, atau lebih tinggi dibanding tahun sebelumnya sebesar 132,34 persen. Sedangkan FDR perbankan syariah nasional pada tahun 2013 sebesar 100,32 persen atau yang tertinggi sepanjang periode 2010-2013.

Dari sisi resiko pembiayaan, perkembangan penyaluran pembiayaan belum diiringi dengan pengelolan resiko pembiayaan yang lebih baik. Hal ini tercermin dari rasio pembiayaan tidak lacar (non performing financing) perbankan umum syariah di Kalimantan Barat tercatat sebesar 0,71 persen pada tahun 2013, atau meningkat 0,14 persen dibanding tahun sebelumnya. pada tahun 2013, angka rasio pembiayaan tidak lancar merupakan yang tertinggi selama periode 2010-2013, namun rasio pembiayaan tidak lancar perbankan umum syariah masih tergolong kecil. Sedangkan jika NPF perbankan syariah di Kalimantan Barat dibandingkan dengan NPF perbankan syariah nasional tahun 2013 sebesar 2,62 persen, maka masih lebih jauh kecil.

Dari sisi demografi, jumlah penduduk Kalimantan Barat yang beragama Islam sebesar 59,22 persen sedangkan jumlah penduduk penduduk yang beragama Islam di Indonesia sebesar 83,16 persen. Jumlah penduduk yang beragama Islam tentu akan menjadikan masyarakat memiliki preferensi yang tinggi terhadap pemilihan perbankan syariah dalam aktifitas transaksi keuangan mereka. Artinya secara tidak langsung maupun langsung prefensi masyarakat terhadap perbankan syariah mendorong semakin berkembangnya perbankan syariah. Selain itu keberagaman suku dan budaya di Kalimantan Barat seperti Suku Melayu, Dayak Jawa, Madura, Bugis, Sunda, Banjar, Minangkabau, Suku Batak dan Tionghoa mencerminkan kesamaan dengan wilayah lainnya di Indonesia.

Disisi lain, adanya persamaan karakteristik provinsi Kalimantan Barat dengan sebagian besar provinsi di Indonesia. Perekonomian masih ditopang oleh sektor pertanian, perkebunan, dan perdagangan serta sektor industri. Mayoritas penduduk di Kalimantan Barat bekerja pada sektor-sektor tersebut. Komoditas pertanian dan perkebunan serta produk turunannya seperti karet dan CPO menjadi komoditas andalan menopang perekonomian daerah.

Dari dipaparkan diatas, kinerja perbankan umum syariah di Kalimantan Barat jauh lebih baik jika dibandingkan kinerja perbankan umum syariah secara nasional. disini, peneliti mencoba untuk menguji dan menganalisis apakah kinerja perbankan umum syariah di Kalimantan Barat berpengaruh dan berkontribusi terhadap perkembangan ekonomi yang tercermin dari PDRB yang dihasilkan provinsi Kalimantan Barat. 


\section{TINJAUAN PUSTAKA}

\subsection{Pengertian dan Tujuan Bank Syariah}

Sesuai dengan UU No. 10 tahun 1998 tentang perubahan UU No 7 tahun 1992 tentang perbankan syariah adalah bank umum yang melaksanakan kegiatan usaha berdasarkan prinsip syariah yang dalam kegiatannya memberikan jasa dalam lalu lintas pembayaran (Arifin, 2002). Prinsip syariah adalah aturan perjanjian berdasarkan hukum Islam antara bank dan pihak lain untuk penyimpanan dana atau pembiayaan kegiatan usaha, atau kegiatan lainnya yang sesuai dengan syariah.

Bank berdasarkan prinsip syariah, seperti halnya bank konvensional juga berfungsi sebagai intermediari yaitu mengerakkan dana dari masyarakat dan menyalurkan kembali dana tersebut kepada masyarakat yang membutuhkan, dalam bentuk fasilitas pembiayaan. Bedanya hanyalah bank syariah melakukan kegiatan usahanya tidak berdasarakan bunga, tetapi berdasarkan sistem bagi hasil atau prinsip syariah yaitu prinsip pembagian keuntungan dan kerugian. Selain pengertian di atas, bank syariah juga diartikan sebagai bank yang beroprasi sesuai dengan prinsip-prinsip syariah Islam, atau bank yang tata cara beroprasiannya mengacu kepada ketentuan AlQu'an dan Al-Hadits (Pertaatmadja, 1991).

Perbankan syariah dibebaskan untuk mengembangkan produknya sendiri menurut teori perbankan Islam, maka produk yang berkembangpun sangat variatif mengikuti produk-produk hukum syariah. Di samping itu, sifat produk perbankan syariah yaitu tidak mengambil bunga sebagai ukuran, berdampak kepada stabilisasi nilai mata uang, karena perbankan syariah tidak bisa dipisahkan dari transaksi riil. Dengan demikian, produk perbankan syariah tidak mengakibatkan bubble economics (Arifin, 1999).

Pemberian suatu fasilitas pembiayaan mempunyai tujuan tertentu. Tujuan pemberian pembiayaan tersebut tidak akan lepas dari misi bank tersebut didirikan. Menurut Kasmir (2002) ada beberapa tujuan utama pemberian suatu pembiayaan kepada nasabah antara lain untuk mencari keuntungan, membantu usaha nasabah, membantu pemerintah. Selain memiliki tujuan, pemberian suatu fasilitas pembiayaan juga memiliki suatu fungsi yang sangat luas. Fungsi pembiayaan yang secara luas tersebut antara lain untuk meningkatkan daya guna uang, meningkatkan peredaran dan lalu lintas uang, meningkatkan daya guna barang, meningkatkan peredaran barang, sebagai alat stabilitas ekonomi, meningkatkan kegairahan berusaha, meningkatkan pemerataan pendapatan, meningkatkan hubungan internasional.

\subsection{Peranan Bank Syariah Terhadap Perkembangan Ekonomi Daerah}

Pada hakekatnya, pembangunan ekonomi bertujuan untuk meningkatkan kesejahteraan masyarakat (social welfare) melalui pencapaian pertumbuhan ekonomi yang cukup tinggi, menjaga kestabilan harga, mengatasi masalah pengangguran, menjaga keseimbangan neraca pembayaran dan pendistribusian pendapatan yang adil dan merata. Perbankan merupakan sektor yang mempunyai pengaruh besar dalam perekonomian 
suatu negara atau daerah, karena bank berfungsi sebagai lembaga perantara untuk menampung dana masyarakat dan menyalurkannya kembali kepada kegiatan perekonomian yang bersifat produktif.

Dalam konteks ini, sektor perbankan memiliki peran yang strategis dalam mengurangi biaya transaksi (transaction cost), melakukkan pembagian resiko (risk sharing) dan mengurangi kemungkinan informasi yang asimetris (asymmetric information). Hal inilah yang diharapkan dari peran vital perbankan, yang mana fungsi intermediasi keuangan bank dalam ekonomi dapat secara optimal dimanfaatkan bagi kebutuhan masyarakat baik oleh surplus unit maupun deficit unit. (Miskhin, 2000). Aktivitas perekonomian yang merupakan kegiatan produktif, baik di sektor barang maupun jasa menjadi sangat banyak tergantung pada sektor perbankan. Bank memainkan peranan yang sangat penting dalam penyaluran pembiayaan terhadap masyarakat.

Pada umumnya alasan orang menggunakan pembiayaan bank untuk kegiatan investasi, menambah modal kerja, maupun untuk konsumsi. Namun dari sisi perbankan, pembiayaan yang lebih banyak diberikan untuk pembiayaan investasi dan modal kerja. Aktivitas perekonomian, khususnya sektor usaha dapat bergerak dengan adanya pembiayaan dari bank. Para pelaku usaha lebih mengandalkan bantuan pembiayaan untuk invesatsi maupun untuk modal kerja dibandingkan dengan modal sendiri. Oleh karena itu peranan pembiayaan bank dalam dunia usaha sangat penting, Karena sebagian besar kegiatan usaha didanai oleh pembiayaan bank.

\subsection{Konsep Pertumbuhan Ekonomi}

Pengukuran pertumbuhan ekonomi secara konvensional biasanya dengan menghitung peningkatan presentase dari Produk Domestik Bruto (PDB). PDB mengukur pengeluaran total dari suatu perekonomian terhadap berbagai barang dan jasa yang baru diproduksi pada suatu saat atau tahun serta pendapatan total yang diterima dari adanya seluruh produksi barang dan jasa tersebut atau secara lebih rinci, PDB adalah nilai pasar dari semua barang dan jasa yang diproduksi di suatu negara dalam kurun waktu tertentu. (Mankiw, 2001)

Pertumbuhan biasanya dihitung dalam nilai riil dengan tujuan untuk menghilangkan adanya inflasi dalam harga dan jasa yang diproduksi sehingga PDB riil mencerminkan perubahan kuantitas produksi. Untuk mengetahui pertumbuhan ekonomi regional, digunakanlah data produk pomestik regional bruto (PDRB) dimana PDRB dapat didefinisikan sebagai nilai barang dan jasa akhir yang dihasilkan oleh sistem perekonomian di suatu wilayah atau daerah dalam kurun waktu tertentu. Sehingga PDRB merupakan suatu ukuran untuk melihat aktivitas perekonomian suatu daerah.

Teori ini dikembangkan dalam waktu hampir bersamaan oleh Roy F. Harrod pada tahun 1948 di Inggris, dan Evsey D. Domar pada tahun 1957 di Amerika Serikat. Walaupun menggunakan perhitungan yang berbeda tetapi memberikan 
hasil yang sama, sehingga keduanya dianggap mengemukakakan ide yang sama dan disebut teori Harrod-Domar. Teori ini melengkapi teori Keynes, dimana Keynes melihatnya dalam jangka pendek (kondisi statis) sedangkan Harrod-Domar melihatnya dalam jangka panjang (kondisi dinamis).

Dalam perekonomian daerah, Richardson merombak kekakuan di atas dengan menggunakan asumsi bahwa perekonomian daerah bersifat terbuka. Artinya, faktorfaktor produksi atau hasil produksi berlebih dapat diekspor dan yang kurang dapat diimpor. Impor dan tabungan adalah kebocoran-kebocoran dalam menyedot output daerah. Sedangkan ekspor dan investasi dapat membantu menyedot output kapasitas penuh dari faktor-faktor produksi yang ada di daerah tersebut. Kelebihan tabungan yang tidak terinvestasikan secara lokal dapat disalurkan ke daerah-daerah lain yang tercermin dalam surplus ekspor. Richardosn (1991) mengemukakan apabila pertumbuhan tenaga kerja melebihi dari apa yang dapat diserap oleh kesempatan kerja lokal maka migrasi neto dapat menyeimbangkan pertumbuhan tenaga kerja (n) dan pertumbuhan ekonomi (g). Jadi dalam sistem perekonomian terbuka persyaratannya menjadi sedikit longgar.

\subsection{Penelitian Sebelumnya}

Penelitian sebelumnya yang bisa menjadi referensi dalam mengembangkan materi dan memiliki kesamaan karakteristik model pendekatan analisis yang digunakan dalam penelitian ini. Sejauh ini penulis baru menemukan beberapa penelitian yang relevan yang dilakukan oleh Rachman dan Sriyanto (2010) mengenai analisis kontribusi kredit investasi, modal kerja dan konsumsi terhadap pertumbuhan ekonomi di Jawa Timur. penelitian yang dilakukan terhadap perbankan umum secara keseluruhan. Hasil penelitian yang dilakukan menujukkan bahwa kontribusi kredit modal kerja, investasi dan konsumsi berpengaruh secara parsial dan simultan terhadap pertumbuhan ekonomi Jawa Timur, kecuali kredit modal kerja secara individu tidak berpengaruh terhadap pertumbuhan ekonomi Jawa Timur. Sedangkan Kredit yang paling berpengaruh terhadap pertumbuhan ekonomi yakni pada kredit investasi dan kredit konsumsi.

Penelitian yang hampir sama juga dilakukan oleh Cholifah (2012) mengenai pengaruh kredit (Kredit Modal Kerja, Kredit Investasi, dan Kredit Konsumsi) terhadap Produk Domestik Regional Bruto Provinsi Kalimantan Barat. Hasil penelitian ini menunjukkan (1) Secara parsial kredit modal kerja mempunyai pengaruh yang signifikan terhadap produk domestik regional bruto. (2) Secara parsial kredit investasi mempunyai pengaruh yang signifikan terhadap produk domestik regional bruto. (3) Secara parsial kredit konsumsi mempunyai pengaruh yang signifikan terhadap produk domestik regional bruto. 


\subsection{Hubungan Pertumbuhan Pembiayaan Modal Kerja, Pembiayaan Investasi dan Pembiayaan Komsumsi terhadap Pertumbuhan Produk Domestik Regional Bruto (PDRB)}

Pembiayaan modal kerja sama halnya dengan pembiayaan investasi, dimana penggunaan dana untuk modal kerja perusahaan dalam rangka pembiayaan aktiva lancar perusahaan, seperti pembelian bahan baku, piutang dan lain-lain. Perusahaan yang memperoleh pembiayaan modal kerja dapat berproduksi lebih optimal karena ada penambahan bahan baku dan tercukupinya kebutuhan produksi perusahaan. Secara berkesinambungan, produksi yang dihasilkan perusahaan juga akan meningkat. Kenaikan jumlah produksi akan menaikkan pertumbuhan ekonomi.

Investasi merupakan salah satu cara untuk meningkatkan pertumbuhan ekonomi. Pembiayaan investasi yang diberikan oleh perbankan syariah akan digunakan untuk membeli barang-barang modal dan peralatan produksi seperti pembukaan pabrik baru, penambahan mesin produksi dan lain-lain. Pembukaan pabrik baru atau penambahan mesin akan meningkatkan kapasitas produksi yang dihasilkan. Peningkatan kapasitas produksi akan meningkatkan jumlah barang dan jasa yang dihasilkan. Dengan demikian, pembiayaan invetasi mendorong kenaikan jumlah barang dan jasa yang di produksi. Kenaikan jumlah barang dan jasa tersebut akan menaikkan pertumbuhan ekonomi.

Konsumsi merupakan indikator utama perhitungan terhadap agregat output yang dihasilkan suatu negara. Dimana konsumsi merupakan penyumbang terbesar di dalam perhitungan pendapatan nasional bagi suatu negara atau daerah. Pembiayaan konsumsi yang di berikan oleh perbankan syariah akan mendorong konsumsi agregat masyarakat, atau meningkatkan permintaan barang dan jasa secara umum. Peningkatan Permintaan agregat masyarakat mendorong terjadinya penambahan jumlah produksi barang dan jasa. Hal ini juga berdampak pada peningkatan kebutuhan bahan baku yang digunakan untuk berproduksi seperti tenaga kerja, bahan baku, penambahan modal kerja dan kebutuhan industri lainnya. Adanya peningkatan produksi barang dan jasa mendorong peningkatan pertumbuhan ekonomi. Jadi pembiayaan konsumsi akan meningkat kan agregat konsumsi masyarakat, kondisi ini menambah pendapatan nasional yang akan berdampak langsung terhadap peningkatan pertumbuhan ekonomi suatu negara atau daerah tersebut.

\section{METODE PENELITIAN}

Berdasarkan tujuannya, penelitian ini termasuk dalam jenis penelitian terapan. Penelitian dilakukan dengan tujuan menerapkan, menguji dan mengevaluasi kemampuan suatu teori yang diterapkan dalam memecahkan masalah-masalah praktis. Adapun penelitian ini menggunakan analisis deskriptif, yaitu data yang digunakan dalam penelitian ini berupa angka-angka atau besaran tertentu yang sifatnya pasti, sehingga data ini memungkinkan untuk dianalisis dengan pendekatan statistik. Sifat penelitian ini 
adalah deskriptif-analisis yaitu penelitian yang menggambarkan dan menjelasakan pengaruh variabel-variabel independen terhadap variabel dependen. Populasi dalam penelitian ini yaitu seluruh bank-bank umum syariah yang ada di Kalimantan Barat pada periode 2009-2013.

Penelitian ini menggunakan data berkala (time seriee data) untuk melihat perkembangan atau perubahan masing-masing variabel yang diamati dari waktu ke waktu. Periode waktu yang digunakan dimulai dari tahun 2009 hingga 2013. Data yang digunakan dalam penelitian ini bersumber pada statistik Perbankan Indonesia yang dicantumkan pada situs resmi Bank Indonesia (www.bi.go.id) dan Badan Pusat Statistik (BPS) Kalimantan Barat.

Sebelum melakukan pengujian terhadap model penelitian, terlebih dahulu dilakukan pengujian asumsi klasik dengan tujuan supaya dapat mengetahui apakah variabel yang akan diteliti telah memenuhi syarat asumsi klasik yang terdiri dari: uji normalitas, uji autokorelasi, uji multikolonieritas, uji heteroskedastisitas, dan uji autokolerasi. Penelitian ini bertujuan melihat pengaruh hubungan antara variabelvariabel independen terhadap variabel dependen dengan menggunakan analisis regresi linier berganda. Dan dalam penghitungan regresi berganda ini, diperlukan adanya penghitungan logaritma natural terhadap variabel dependen. Hal ini dikarenakan nilai data yang terlalu besar berupa data nominal. Perlakuan seperti itu dimaksudkan untuk membuat data setara dengan data variabel independennya yang berupa data rasio.

Model ini memperlihatkan hubungan dan pengaruh antara variabel bebas (pertumbuhan pembiayaan Modal Kerja $\left(\mathrm{X}_{1}\right)$, pertumbuhan pembiayaan Investasi $\left(\mathrm{X}_{2}\right)$ dan dan pertumbuhan pembiayaan Konsumsi $\left(\mathrm{X}_{3}\right)$ dan pertumbuhan produk domestik regional bruto variabel terikat (Y), bentuk persamaannya sebagai berikut:

$Y=\alpha+\beta_{1} X_{1}+\beta_{2} X_{2}+\beta_{3} X_{3}+e$

Setelah melakukan pemilihan model dan melakukan pengolahan data yang menggunakan program SPSS. Kriteria-kriteria statistika yang akan dilakukan dalam analisa data, yaitu Uji t, Uji F dan Koefisien Determinasi.

\section{TEMUAN DAN PEMBAHASAN}

\subsection{Hasil Uji Model}

Analisis ini digunakan untuk mengetahui pengaruh pembiayaan modal kerja, investasi dan konsumsi perbankan syariah terhadap pertumbuhan PDRB Kalimantan Barat. Tabel 4 merupakan ringkasan hasil pengujian regresi linear berganda dengan menggunakan SPSS 20. 
Tabel 4. Hasil Uji Regresi

\begin{tabular}{lcccc}
\hline \multicolumn{1}{c}{ Variabel } & Koefisien Regresi & Beta & t hitung & Signifikansi \\
\hline Constant $)$ & 4,111 & & 11,384 &, 000 \\
MK &,- 006 &,- 124 &,- 573 &, 574 \\
I &, 012 &, 168 & 1,953 &, 035 \\
K &, 029 &, 779 & 3,823 &, 001 \\
\hline
\end{tabular}

Dari Tabel 4 secara matematis dapat ditulis ke dalam persamaan sebagai berikut:

$\mathrm{Y}=4,111-0,006 \mathrm{X}_{1}+0,012 \mathrm{X}_{2}+0,029 \mathrm{X}_{3}$

Adapun arti dari koefisien regresi tersebut adalah sebagai berikut:

- Konstanta $(\alpha)$

Artinya apabila variabel pertumbuhan pembiayaan Modal kerja, Investasi, dan Konsumsi tidak mengalami perubahan atau sama dengan nol maka pertumbuhan PRDB Kalimantan Barat sebesar 4,111 persen.

- $\quad$ b1 $=-0,006$

Artinya apabila pertumbuhan pembiayaan Modal Kerja meningkat 1 (satu) satuan maka pertumbuhan PDRB Kalimantan Barat akan berkurang sebesar 0,006 persen dengan asumsi variabel lain tetap.

- $\quad \mathrm{b} 2=0,012$

Artinya apabila pertumbuhan pembiayaan Investasi meningkat 1 (satu) satuan maka pertumbuhan PDRB Kalimantan Barat meningkat sebesar 0,012 persen dengan asumsi variabel lain tetap.

- b3 = 0,029

Artinya apabila pertumbuhan pembiayaan Konsumsi meningkat 1 (satu) satuan maka pertumbuhan PDRB Kalimantan Barat meningkat sebesar 0,029 persen dengan asumsi variabel lain tetap.

\subsection{Pembahasan}

Pengaruh pertumbuhan pembiayaan modal kerja, investasi dan konsumsi memiliki nilai konstanta yang positif. Nilai konstanta sebesar 4,111 (tabel 4.5) bermakna bahwa jika pertumbuhan pembiayaan modal kerja, investasi dan konsumsi tidak mengalami perubahan, maka nilai pertumbuhan PDRB sebesar 4,111 persen.

Pengaruh Pertumbuhan Pembiayaan Modal Kerja Perbankan Umum Syariah Terhadap Pertumbuhan PDRB Kalimantan Barat

Pembiayaan modal kerja adalah pembiayaan jangka pendek yang diberikan kepada perusahaan untuk membiayai kebutuhan modal kerja usahanya berdasarkan 
prinsip syariah. Jangka waktu pembiayaan modal kerja maksimum satu tahun dan dapat diperpanjang sesuai kebutuhan. Perusahaan (debitur) yang memperoleh pembiayaan modal kerja dapat berproduksi lebih optimal karena ada penambahan bahan baku dan tercukupinya kebutuhan produksi perusahaan. Secara berkesinambungan, produksi yang dihasilkan perusahaan juga akan meningkat. Kenaikan jumlah produksi akan menaikkan pertumbuhan ekonomi.

Berdasarkan hasil regresi dalam penelitian ini diperoleh nilai koefisien regresi 0,006 dan nilai sig. t hitung sebesar -,574. Nilai koefisien sebesar -0,006 dapat diartikan bahwa apabila pertumbuhan pembiayaan modal kerja meningkat sebesar 1 satuan sedangkan variabel lainnya tetap, maka PDRB mengalami penurunan sebesar 0,006 persen. Pembiayaan modal kerja bernilai negatif mengindikasikan pembiyaan modal kerja memiliki hubungan yang tidak searah. Sedangkan dengan taraf signifikansi 5\% $(0,05)$, maka sig.t 0,574>0,05 sehingga dapat disimpulkan bahwa pertumbuhan pembiayaan modal kerja tidak berpengaruh positif dan signifikan pada pertumbuhan PDRB. Dengan demikian, hipotesis yang menyatakan bahwa pertumbuhan pembiayaan modal kerja berpengaruh positif signifikan terhadap pertumbuhan PDRB ditolak.

Hasil ini mengindikasikan pertumbuhan pembiayaan modal kerja perbankan umum syariah tidak begitu efektif dan efisien dalam meningkatkan pertumbuhan PDRB. Hal ini dikarenakan pembiayaan modal kerja yang diberikan kepada sektor industri belum mampu mendorong peningkatan produksi yang signifikan dan sumbangan terhadap laju pertumbuhan PDRB1. Kontribusi sektor industri pengolahan terhadap pertumbuhan PDRB Kalimantan Barat sebesar 0,68 persen pada tahun 2013 dari laju pertumbuhan sebesar 6,3 persen.

Berdasarkan Kajian Ekonomi Regional Bank Indonesia (2013) menurunnya kontribusi sektor industri didorong oleh penurunan dua komoditas ekspor andalan produksi industri pengolahan yaitu karet dan CPO. Jumlah volume produksi Industri pengolahan karet di Kalimantan Barat bergerak fluktuatif. Pada tahun 2011 dan tahun 2012 terjadi penurunan volume produksi dan mengalami kontraksi atau pertumbuhan yang negatif. Kondisi tersebut berlanjut hingga triwulan ketiga tahun 2013, sehingga tidak terjadi pertumbuhan yang signifikan pada sektor ini. Disisi harga, harga karet di level internasional masih menunjukkan tren pelemahan. 


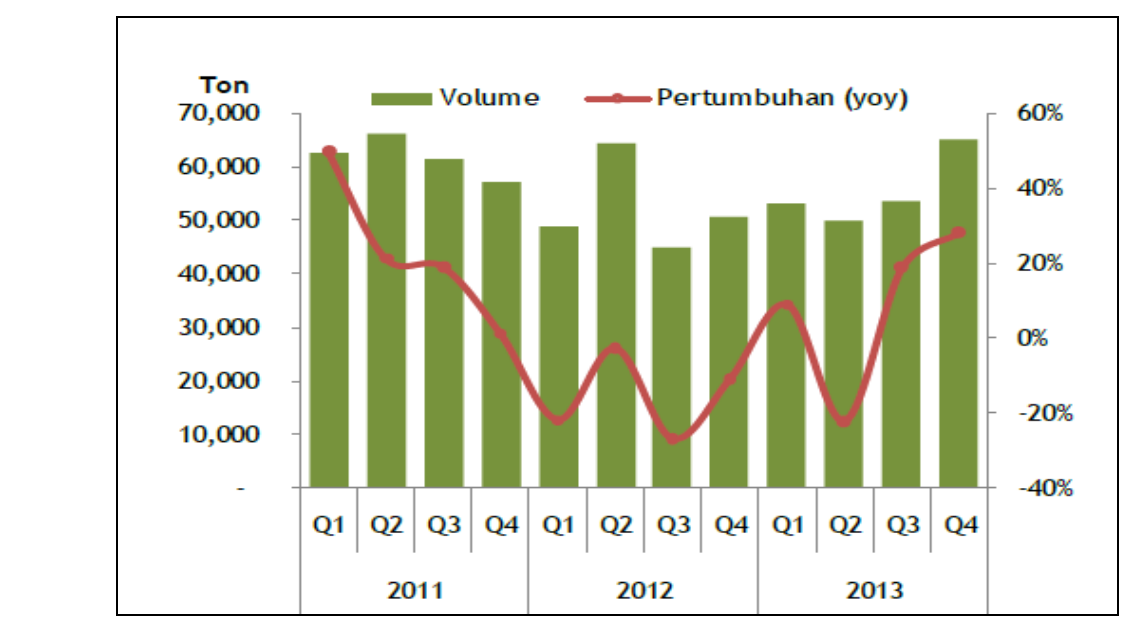

Sumber: KER Bank Indonesia, 2013

\section{Gambar 1. Grafik Volume dan Pertumbuhan Industri Pengolahan Karet}

Sementara itu, kinerja sektor industri CPO dibayang-bayangi tren penurunan, dimana pada triwulan keempat 2013, prodksi CPO tercatat masih mengalami kontraksi sebesar 10,41 persen. Kontraksi tersebut antara lain disebabkan oleh rendahnya pasokan TBS (tandan buah segar sawit. Disamping itu permintaan global mengalami penurunan, sehigga menyebabkan harga CPO semakin turun.

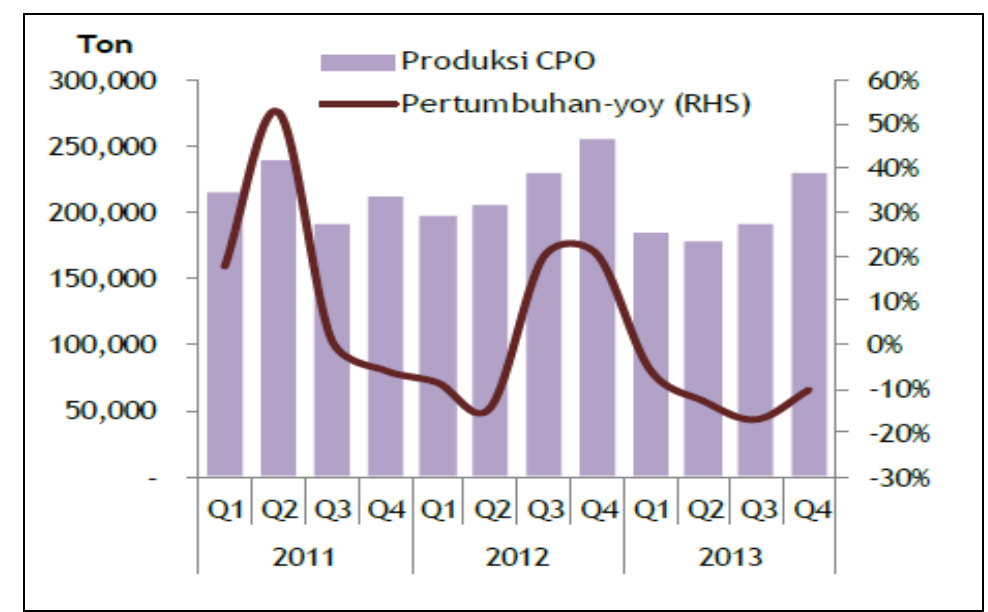

Sumber: KER Bank Indonesia, 2013

\section{Gambar 2. Grafik Volume dan Pertumbuhan Industri Pengolahan CPO}

Jika ditinjau dari kebijakan perusahaan terhadap penggunaan dana, hal ini bisa disebabkan oleh pembiayaan modal kerja yang diberikan oleh perbankan syariah terhadap perusahaan (debitur) dipergunakan untuk menjaga produksi yang dihasilkan perusahaan. Pembiayaan modal kerja dipergunakan perusahaan untuk pembelian kekurangan bahan baku, membayar gaji atau upah pegawai, overhead cost dan lain-lain. Pemberian pembiayaan modal kerja oleh perbankan umumnya berjangka waktu pendek dan menengah, sehingga hasil atau dampak pembiayaan yang diberikan belum berpengaruh signifikan terhadap peningkatan sektor industri. 
Dalam penelitian ini pertumbuhan pembiayaan modal kerja memiliki hubungan tidak searah dan tidak signifikan, maka penelitian ini sesuai dengan penelitian yang pernah dilakukan oleh Zainal Fathor Rachman dan Agus Sriyanto (2010) mengenai Analisis kontribusi kredit investasi, modal kerja dan konsumsi terhadap pertumbuhan ekonomi di Jawa Timur periode 2005-2009. Hasil penelitian ini menunjukkan bahwa variabel pembiayaan modal kerja tidak berpengaruh terhadap pertumbuhan PDRB Kalimantan Barat.

Pengaruh Pertumbuhan Pembiayaan Investasi Perbankan Umum Syariah Terhadap Pertumbuhan PDRB Kalimantan Barat

Pembiayaan investasi yang diberikan perbankan syariah adalah pembiayaan jangka menengah/panjang yang diberikan kepada perusahaan (debitur) utuk membiayai barang-barang modal dalam rangka rehabilitasi, modernisasi, perluasan ataupun pendirian proyek baru, misalnya untuk pembelian mesin-mesin, bangunan dan tanah untuk pabrik, yang pelunasannya dari hasil usaha dengan barang-barang modal yang dibiayai.

Berdasarkan hasil regresi diperoleh nilai koefisien regresi 0,012 dan nilai sig. $\mathrm{t}$ hitung sebesar 0,035. Nilai koefisien sebesar 0,012 dapat diartikan bahwa bila pertumbuhan pembiayaan investasi meningkat sebesar 1 satuan sedangkan variabel lainnya tetap, maka PDRB mengalami peningkatan sebesar 0,012 persen. Pertumbuhan pembiayaan investasi bernilai positif mengindikasikan pembiyaan investasi memiliki hubungan yang searah. Sedangkan dengan taraf signifikansi 5\% (0,05), maka sig.t 0,035 $<0,05$ sehingga dapat disimpulkan bahwa pertumbuhan pembiayaan investasi berpengaruh positif dan signifikan pada pertumbuhan PDRB. Dengan demikian, hipotesis yang menyatakan bahwa pertumbuhan pembiayaan investasi berpengaruh positif signifikan terhadap pertumbuhan PDRB diterima.

Hasil penelitian ini yang signifikan dimungkinkan karena pembiayaan investasi yang diberikan perbankan syariah digunakan secara efektif dan optimal oleh debitur (perusahaan). Para debitur (perusahaan) menggunakan dana untuk pengembangan perusahaan seperti pembelian mesin baru, perluasan pabrik, dan pembukaan pabrikpabrik baru. Pembukaan pabrik baru atau penambahan mesin akan meningkatkan kapasitas produksi yang dihasilkan. Peningkatan kapasitas produksi akan meningkatkan jumlah barang dan jasa yang dihasilkan. Dengan demikian, pembiayaan invetasi mendorong kenaikan jumlah barang dan jasa yang di produksi. Kenaikan jumlah barang dan jasa tersebut akan menaikkan pertumbuhan ekonomi.

Implikasi hasil penelitian ini searah dengan realiasasi investasi di Kalimantan Barat periode tahun 2010-2013. Realisasi investasi mengalami tren peningkatan sejak tahun 2010 hingga tahun 2012, meskipun mengalami kontraksi pada tahun 2013. Peningkatan realisasi investasi swasta khususnya penanaman modal dalam negeri (PMDN) dimana total realisasi PMDN pada tahun 2011 dan tahun 2012 masing-masing 
mencapai 1.404 Miliar (tumbuh 19,87 persen dari tahun 2010) dan 2.811 Miliar (tumbuhan 100,21 persen dari tahun 2011). Sedangkan untuk tahun 2013 mengalami perlambatan dengan total realisasi sebesar 2.522,10 miliar. Perlambatan ini diperkirakan dipengaruhi oleh kondisi ketidakpastian perekonomian global serta persepsi melambatnya perekonomian nasional. Namun selama periode tahun 2009 hingga 2013 realisiasi investasi secara rata-rata tumbuh positif. Realisasi investasi tersebut secara langsung mendorong pertumbuhan perekonomian Kalimantan Barat.

Pembiayaan investasi perbankan syariah dalam penelitian ini memiliki nilai (pengaruh) lebih kecil dibandingkan dengan pembiayaan konsumsi. Hal ini juga tercermin dari kontribusi penggunaan investasi terhadap pertumbuhan PDRB Kalimantan Barat pada tahun 2013 hanya sebesar 0,57 persen, kontribusi konsumsi terhadap PDRB sebesar 4,27 persen. Jika kita melihat pembiayaan investasi dari sisi waktu, pembiayaan investasi biasanya diberikan dengan jangka waktu pengembalian yang lebih panjang, sehingga lebih berdampak positif dan secara langsung mendorong peningkatan pertumbuhan ekonomi. Investasi baru yang dilakukan oleh debitur (perusahaan) memberikan kesempatan kerja baru kepada masyarakat, permintaan bahan baku, dan faktor-faktor produksi lainnya.

Dalam penelitian ini pertumbuhan pembiayaan investasi memiliki hubungan searah (positif) dan signifikan, maka penelitian ini sesuai dengan penelitian yang pernah dilakukan oleh Rachman dan Sriyanto (2010) mengenai "Analisis kontribusi kredit investasi, modal kerja dan konsumsi terhadap pertumbuhan ekonomi di Jawa Timur periode 2005-2009". Hasil penelitian ini menunjukkan bahwa variabel pertumbuhan pembiayaan investasi berpengaruh terhadap pertumbuhan PDRB Kalimantan Barat. Penelitian lain yang pernah dilakukan oleh Cholifah (2012) mengenai "Pengaruh kredit (kredit modal kerja, kredit investasi, dan kredit konsumsi) terhadap Produk Domestik Regional Bruto Provinsi Kalimantan Barat" menunjukkan kredit investasi memiliki hubungan yang positif dan signifikan terhadap pertumbuhan PDRB.

\section{Pengaruh Pertumbuhan Pembiayaan Konsumsi Perbankan Umum Syariah Terhadap Pertumbuhan PDRB Kalimantan Barat}

Pembiayaan konsumtif merupakan pembiayaan yang diberikan oleh perbankan syariah kepada nasabah (debitur) yang digunakan untuk memenuhi kebutuhan konsumsi, yang akan habis digunakan untuk memenuhi kebutuhan. Pembiayaan konsumtif lebih diperuntukkan kepada perseorangan. Pembiayaan konsumsi menciptakan permintaan agregat masyarakat akan barang dan jasa mengalami peningkatan. Tingginya permintaan agregat mendorong adanya tambahan produksi yang dilakukan perusahaan. Sehingga secara bersamaan akan meningkatkan pertumbuhan ekonomi.

Berdasarkan hasil regresi diperoleh nilai koefisien regresi 0,029 dan nilai sig. $\mathrm{t}$ hitung sebesar 0,001. Nilai koefisien sebesar 0,029 dapat diartikan bahwa bila pertumbuhan pembiayaan investasi meningkat sebesar 1 satuan sedangkan variabel 
lainnya tetap, maka PDRB mengalami peningkatan sebesar 0,029 persen. Pertumbuhan pembiayaan konsumsi bernilai positif mengindikasikan pertumbuhan pembiayaan investasi memiliki hubungan yang searah. Sedangkan dengan taraf signifikansi 5\% (0,05), maka sig.t $0,001<0,05$ sehingga dapat disimpulkan bahwa pertumbuhan pembiayaan konsumsi berpengaruh positif dan signifikan pada pertumbuhan PDRB. Dengan demikian, hipotesis yang menyatakan bahwa pertumbuhan pembiayaan konsumsi berpengaruh positif signifikan terhadap pertumbuhan PDRB diterima.

Tabel 5. PDRB Penggunaan Provinsi Kalimantan Barat tahun 2012-2013 (dlm Milyar)

\begin{tabular}{|c|c|c|c|c|}
\hline \multirow[t]{2}{*}{ Jenis Pengeluaran } & \multicolumn{2}{|c|}{$\begin{array}{c}\text { Atas Dasar Harga Konstan (Rp } \\
\text { Miliar) }\end{array}$} & \multirow{2}{*}{$\begin{array}{c}\text { Laju } \\
\text { Pertumbuhan } \\
2013 \\
\text { (persen) }\end{array}$} & \multirow{2}{*}{$\begin{array}{c}\text { Sumber } \\
\text { Pertumbuhan } \\
2013 \\
\text { (persen) }\end{array}$} \\
\hline & 2012 & 2013 & & \\
\hline Konsumsi Rumah Tangga & $17.994,97$ & $19.096,88$ & 6,12 & 3,24 \\
\hline $\begin{array}{l}\text { Konsumsi Lembaga Swasta } \\
\text { Nirlaba }\end{array}$ & 325,58 & 344,46 & 5,8 & 0,06 \\
\hline Konsumsi Pemerintah & $4.205,29$ & $4.552,12$ & 8,25 & 1,02 \\
\hline $\begin{array}{l}\text { Pembentukan Modal Tetap } \\
\text { Domestik Bruto }\end{array}$ & $9.546,87$ & $9.895,76$ & 3,65 & 1,03 \\
\hline Perubahan Stok & $1.201,62$ & $1.021,01$ & - & - \\
\hline Ekspor Barang dan Jasa & $100.506,56$ & $10.940,22$ & 4,13 & 1,28 \\
\hline Dikurangi Impor Barang dan Jasa & $9.773,33$ & $9.775,35$ & 0,02 & 0,01 \\
\hline PDRB Kalimantan Barat & $34.007,75$ & $36.075,10$ & 6,08 & 6,08 \\
\hline
\end{tabular}

Sumber: KER Bank Indonesia, 2013

Konsumsi tercatat sebagai komponen penting bagi pertumbuhan ekonomi Kalimantan Barat. Hal ini mengindikasikan bahwa pembiayaan konsumsi mendorong tingginya pengeluaran masyarakat yang tercermin dari meningkatnya konsumsi rumah tangga. Berdasarkan PDRB penggunaan, pertumbuhan tertinggi terjadi pada komponen konsumsi pemerintah sebesar 8,25 persen, komponen konsumsi rumah tangga sebesar 6,12 persen, dan komponen lembaga swasta nirlaba 5,80 persen. Sedangkan komponen lainnya yaitu komponen ekspor barang dan jasa tumbuh 4,13 persen, Pembentukan Modal Tetap Bruto (PMTB) sebesar 3,65 persen dan komponen impor barang dan jasa mengalami pertumbuhan pada tahun 2013 sebesar 0,02 persen. Sumber utama pertumbuhan ekonomi tahun 2013 dari sisi penggunaan berasal dari komponen konsumsi rumah tangga menyumbang 3,24 persen, diikuti kemudian oleh komponen ekspor 1,28 persen, komponen pembentukan Modal tetap Bruto menyumbang 1,03 persen, konsumsi pemerintah memberikan sumbangan sebesar 1,02 persen. Sedangkan komponen konsumsi lembaga swasta nirlaba memberikan sumbangan 0,06 persen bahkan komponen impor barang dan jasa mengurangi laju pertumbuhan sebesar 0,01 persen.

Masih terjaganya konsumsi tersebut antara lain dipengaruhi oleh diselenggarakannya berbagai sepanjang tahun dimana dari 12 bulan terdapat 8 bulan 
yang memiliki kegiataan, baik perayaan hari raya mapuan kegiatan adat seperti Imlek, Cap Go meh, Sembahyang Kubur serta Gawai Dayak. Selain itu, penyelenggaraan kegiatan berskala nasional, dan Pemilihan Kepada Daerah Gubernur, wali kota maupun bupati memberikan dampak yang positif terhadap konsumsi masyarakat. Secara umum berdasarkan kontribusi penggunaan, konsumsi menyumbang sebesar 4,27 persen terhadap pertumbuhan PDRB Kalimantan Barat pada tahun 2013, kemudian diikuti oleh net ekspor dan investasi yang masing-masing menyumbang sebesar 1,24 persen dan 0,57 persen.

Hasil penelitian ini signifikan dimungkinkan karena pembiayaan konsumsi yang dilakukan oleh perbankan syariah berhasil menciptakan permintaan-permintaan baru atau adanya peningkatan daya beli masyarakat. Konsumen yang tidak memiliki kemampuan untuk membayar tunai terjembatani dengan fasilitas pembiayaan ini. Disisi lain, perbankan memberikan banyak kemudahan kepada para konsumen, seperti persyaratan yang mudah, jangka waktu pembiayaan yang dapat disesuaikan dengan kebutuhan konsumen baik jangka pendek maupun jangka panjang. Perbankan syariah juga menyediakan skema pembayaran dan kepemilikan yang dapat dipilih konsumen, baik murabahah, ijarah dan isthisna'.

\section{KESIMPULAN}

Berdasarkan analisis dan pembahasan pada bab-bab sebelumnya dapat diambil kesimpulan sebagai berikut: (1) Variabel pertumbuhan pembiayaan Modal Kerja (MK) secara individu tidak berpengaruh terhadap pertumbuhan PDRB Kalimantan Barat, sedangkan variabel pertumbuhan pembiayaan Investasi (I) dan Konsumsi (K) berpengaruh positif dan signifikan terhadap tingkat pertumbuhan PDRB Kalimantan Barat periode 2009-2013. Namun secara bersama-sama (simultan) ketiga variabel Modal Kerja (MK), Investasi (I) dan Konsumsi (K) berpengaruh signifikan terhadap tingkat pertumbuhan PDRB Kalimantan Barat. (2) Diantara variabel-variabel pertumbuhan pembiayaan Modal Kerja (MK), Investasi (I) dan Konsumsi (K) yang paling dominan adalah variabel pembiayaan Konsumsi. Kemudian diikuti oleh pembiayaan Investasi dan Modal kerja.

Keterbatasan penelitian ini adalah Periode penelitian menggunakan periode triwulanan, sementara data survei statistik perbankan syariah dengan mengelompokkan data pembiayaan menurut jenis penggunaan yakni pembiayaan modal kerja, investasi, dan konsumsi untuk masing-masing daerah dimulai dari tahun 2008. Dengan rentang waktu tersebut, jumlah observasi yang digunakan tidak terlalu banyak. Oleh karena itu, diperlukan rentang waktu data (time series) yang lebih panjang untuk memperoleh nilai prediksi yang lebih baik. Selain itu, variabel penelitian hanya berkisar pada kemampuan perbankan syariah menyalurkan pembiayaan tanpa memperdulikan faktor-faktor lain seperti inflasi, suku bunga, investasi asing dan situasi ekonomi global. 


\section{DAFTAR PUSTAKA}

Arifin, Z. (1999). Memahami Bank Syariah Lingkup, Peluang, Tantangan dan Prospek. Jakarta: Alvabet.

Arifin, Z. (2002). Dasar Dasar Manajemen Bank Syariah. Jakarta: Alvabet.

Bank Indonesia. (2013). Statistik Perbankan Syariah (SPS), edisi Desember. Jakarta: Bank Indonesia

Bank Indonesia. (2009). Kajian Ekonomi Regional (KER), edisi Kuartal IV. Pontianak: Bank Indonesia.

Bank Indonesia. (2010a). Kajian Ekonomi Regional (KER), edisi Kuartal IV. Pontianak: Bank Indonesia.

Bank Indonesia. (2011b). Kajian Ekonomi Regional (KER), edisi Kuartal IV. Pontianak: Bank Indonesia.

Bank Indonesia. (2012c). Kajian Ekonomi Regional (KER), edisi Kuartal IV. Pontianak: Bank Indonesia.

Bank Indonesia. (2013d) Kajian Ekonomi Regional (KER), edisi Kuartal IV. Pontianak: Bank Indonesia.

Karim, A. A. (2006). Bank Islam Analisis Fiqih dan Keuangan. Jakarta: PT. RajaGrafindo Persada

Richardson. H. W. (1991). Dasar-Dasar Ilmu Ekonomi Regional. Depok: Lembaga Penerbit Fakultas Ekonomi Universitas Indonesia.

Herdiansyah, A. (2008), Pengaruh Pembiayaan Modal Kerja Terhadap Pendapatan Usaha Nasabah (Studi Pada Bank DKI Syariah Cabang Wahid Hasyim) (Skripsi yang tidak dipublikasikan), UIN Syarif Hidayatullah, Indonesia.

Ghozali, I. (2011). Aplikasi Analisis Multivariate Dengan Program IBM SPSS 19. Semarang: Badan Penerbit Universitas Diponegoro.

Wahyudi, I. , Dewi, M. K., Rosmanita, F., Prasetyo, M. B. \& Putri, N. I. S. (2013). Manajemen Risiko Bank Islam. Jakarta: Salemba Empat

Perwataatmadja, K. A. \& Antonio, M. S. (1992). Apa dan Bagaimana Bank Islam. Yogyakarta: Dana Bakti Wakaf. 
Kasmir. (2008) Bank dan Lembaga Keuanngan Lainnya. Jakarta: PT. RadjaGrafindo Persada.

Kristanto, R. (2008). Konsep Pembiayaan Dengan Prinsip Syariah dan Aspek Hukum Dalam Pemberian Pembiayaan Pada PT. Bank Rakyat Indonesia (Persero)TBK. Kantor Cabang Syariah Semarang (Tesis yang tidak dipublikasikan), Universitas Diponegoro, Indonesia.

Muhammad. (2011). Manajemen Bank Syariah (Ed. 2). Yogyakarta: UPP STIM YKPN.

Syafi'I, A. M. (2001) Bank Syariah : Dari Teori Ke Praktek. Jakarta: Gema Insani Press.

Pratiwi, W.(2009). Analisis Pengaruh Penyaluran Kredit Terhadap Pertumbuhan Ekonomi Kalimantan Barat (Skripsi yang tidak dipublikasikan), Universitas Tanjungpura, Indonesia

Sukirno, S. (2004). Ekonomi Pembangunan: Proses, Masalah dan Dasar Kebijaksanaan. Jakarta: LPFE- UI.

Rahman, Z. F. \& Sriyanto, A. (2010). Analisis Kontribusi Kredit Investasi, Modal Kerja dan Konsumsi Terhadap Pertumbuhan Ekonomi Jawa Timur. Diakses dari http://www.e-jurnal.com/2014/01/analisis-kontribusi-investasi-kredit.html

Rivai, V. \& Arifin, A. (2010). Islamic Banking: Sebuah Teori ,Konsep, dan Aplikasi. Jakarta: Bumi Aksara.

Sumitro, W. (1996). Azaz Azaz Perbankan Islam Dan Lembaga-Lembaga Terkait (BMUI dan Takaful) di Indonesia. Jakarta: PT. RadjaGrafindo Persada. 